\title{
КОРЕКЦІЯ ПРООКСИДАНТНО-АНТИОКСИДАНТНОЇ РІВНОВАГИ В ПАЦІЄНТІВ ІЗ КРИТИЧНОЮ ІШЕМІЄЮ НИЖНІХ КІНЦІВОК ТА ВИСОКИМ РИЗИКОМ РОЗВИТКУ РЕПЕРФУЗІЙНО-РЕОКСИГЕНАЦЙНИХ УСКЛАДНЕНЬ
}

Вступ. Облітеруючий атеросклероз магістральних перифреричних судин становить більще $20 \%$ випадків усієї серцево-судинної патології, тобто понад 3 \% загальної кількості населення. На сучасному етапі особливої гостроти набуває проблема лікування хворих із термінальними стадіями оклюзивних захворювань артерій нижніх кінцівок - "критичною ішемією", що відповідає 3-4 стадіям хронічної ішемії за класифрікацією Б. В. Покровського або III-IV - за Fontaine.

Мета дослідження - вивчити можливість корекції прооксидантно-антиоксидантної системи в пацієнтів із хронічною критичною ішемією нижніх кінцівок та високим ризиком розвитку реперфузійно-реоксигенаційних ускладнень після реконструктивних операцій.

Методи дослідження. В основу роботи покладено аналіз комплексного обстеження та хірургічного лікування 220 хворих на облітеруючий атеросклероз аорти і магістральних артерій нижніх кінцівок. Активність складових прооксидантно-антиоксидантної системи визначали за допомогою спектрофотометричних методів, оптичну густину вимірювали на спектрофротометрі "Biomat 5" (Велика Британія).

Результати й обговорення. 3 метою корекції прооксидантно-антиоксидантної рівноваги в передопераційний період призначали альфра-токофрерол та кверцитин. Застосування препаратів дало можливість стабілізувати активність прооксидантно-антиоксидантної системи на момент проведення операційного втручання. Зокрема, у вказаний період знизилась активність вільнорадикального окиснення, про що свідчило зменшення в 1,3 раза $(p<0,05)$ вмісту активних продуктів тіобарбітурової кислоти в сироватці крові. Водночас знизився в 1,5 раза $(p<0,05)$ вміст у сироватці крові супероксиддисмутази при незначному зростанні вмісту каталази та незмінному вмісті церулоплазміну. Результати дослідження підтверджують, що реваскуляризація нижніх кінцівок сприяє активації прооксидантно-антиоксидантної системи і, передусім, підвищенню активності вільнорадикального окиснення.

Висновок. Застосування в передопераційний період у пацієнтів із високим ризиком виникнення реперфузійно-реоксигенаційних ускладнень альфа-токоферолу і кверцитину дає можливість запобігти значним порушенням розвитку ендотеліальної диссрункції та погіршенню фрункціонування мікроциркуляторного русла за рахунок підвищеної здатності прооксидантно-антиоксидантної рівноваги.

КЛЮЧОВІ СЛОВА: прооксидантно-антиоксидантна система; реперфузійно-реоксигенаційні ускладнення; альфа-токоферол; кверцитин; вільнорадикальне окиснення.

ВСТУП. Облітеруючий атеросклероз магістральних перифреричних судин становить більше 20 \% випадків усієї серцево-судинної патології, тобто понад 3 \% загальної кількості населення [1]. Особливість цієї патології полягає в невпинному прогресуванні захворювання, що характеризується наростанням клінічних проявів [2]. На сучасному етапі особливої гостроти набуває проблема лікування хворих із термінальними стадіями оклюзивних захворювань артерій нижніх кінцівок - "критичною ішемією", що відповідає (с) О. Б. Колотило, 2019.
3-4 стадіям хронічної ішемії за класифрікацією Б. В. Покровського або III-IV - за Fontaine [3]. Критична ішемія відповідає 4, 5 і 6 категоріям (grade II-III) за Rutherford згідно з 2017 ESC Guidelines on the Diagnosis and Treatment of Peripheral Arterial Diseases, in collaboration with the European Society for Vascular Surgery [4].

Дослідження активності компонентів прооксидантно-антиоксидантної системи сироватки крові пацієнтів з атеросклеротичним ураженням аорти та магістральних артерій за умови хронічної критичної ішемії і на етапах раннього після- 
операційного періоду виявили характерні зміни, що свідчать про активацію процесів вільнорадикального окиснення, викликану не лише патологією, але й операційним втручанням і ускладненнями, які виникають внаслідок розвитку реперфрузії [5].

Мета дослідження - вивчити можливість корекції прооксидантно-антиоксидантної системи в пацієнтів із хронічною критичною ішемією нижніх кінцівок та високим ризиком розвитку реперфузійно-реоксигенаційних ускладнень після реконструктивних операцій.

МЕТОДИ ДОСЛІДЖЕННЯ. В основУ РоботИ покладено аналіз комплексного обстеження та хірургічного лікування 220 хворих на облітеруючий атеросклероз аорти і магістральних артерій нижніх кінцівок.

Активність складових прооксидантно-антиоксидантної системи визначали за допомогою спектрофотометричних методів, оптичну густину вимірювали на спектрофотометрі "Biomat 5" (Велика Британія) [6].

Критерієм інтенсивності пероксидного окиснення ліпідів був вміст активних продуктів тіобарбітурової кислоти (ТБК-АП) у сироватці крові. Рівень ТБК-АП оцінювали за кольоровою реакцією з 2-тіобарбітуровою кислотою (ТБК) за присутності іонів $\mathrm{Fe}^{3+}$. У пробірку з 0,05 мл сироватки крові додавали 0,2 мл 0,27 \% розчину $\mathrm{FeCl}_{3}$ і через 10 хв доводили до 1,8 мл 0,2 M гліциновим бусером (рН 3,6). Після додавання 1,55 мл 0,8 \% розчину ТБК суміш кип'ятили на водяній бані впродовж 15 хв, охолоджували, додавали 1 мл 20 \% трихлороцтової кислоти, 2 мл хлорофрорму, перемішували і центрисругували протягом 15 хв при 3000 об./хв [7].

Рівень церулоплазміну (ЦП) визначали модисікованим методом Ревіна, що ґрунтується на окисненні р-оренілендіаміну з участю ЦП із залишками реакції розчином фртористого натрію, оптичну густину вимірювали при 540 нм [8].

Активність супероксиддисмутази (СОД) визначали в модельній системі утворення супероксидних аніонів під час взаємодії нікотинамідаденіндинуклеотиду і френазинметасульфату.
Здатність СОД конкурувати за супероксидні аніони виявляли за ступенем інгібіції відновлення нітросинього тетразолію до гідразинтетразолію [9].

РЕЗУЛЬТАТИ Й ОБГОВОРЕННЯ. ПУСКОВИМ чинником у розвитку реперфузійно-реоксигенаційного синдрому вважають надходження в ішемізовані тканини кисню. Водночас розвивається невідповідність між кількістю кисню в артеріальній крові й можливостями реоксигенованих тканин його утилізувати. Обидва вказані процеси тісно пов'язані з кисневотранспортною фрункцією крові та прооксидантно-антиоксидантною рівновагою [10].

3 метою корекції прооксидантно-антиоксидантної рівноваги в передопераційний період призначали альфа-токоферол та кверцитин.

Застосування препаратів дало можливість стабілізувати активність прооксидантно-антиоксидантної системи на момент проведення операційного втручання (табл. 1). Зокрема, у вказаний період знизилась активність вільнорадикального окиснення, про що свідчило зменшення в 1,3 раза $(p<0,05)$ вмісту ТБК-АП у сироватці крові. Водночас знизився в 1,5 раза $(\mathrm{p}<0,05)$ вміст у сироватці крові СОД при незначному зростанні вмісту каталази та незмінному вмісті ЦП.

Однак передопераційне зниження активності прооксидантно-антиоксидантної системи значно активувалося після проведення реваскуляризації нижніх кінцівок. Зокрема, вміст ТБК-АП і каталази в сироватці крові зростав, відповідно, в 1,3 $(p<0,05)$ та 1,9 $(p<0,001)$ раза порівняно 3 передопераційним періодом. Відмічено незначне збільшення вмісту в сироватці крові СОД та ЦП.

Результати дослідження підтверджують, що реваскуляризація нижніх кінцівок сприяє активації прооксидантно-антиоксидантної системи і, передусім, підвищенню активності вільнорадикального окиснення.

Отримані результати дослідження активності прооксидантно-антиоксидантної системи у хворих із передопераційною спеціальною підготовкою все ж відрізняються від результатів такого дослідження в пацієнтів із стандартною

Таблиця 1 - Активність прооксидантно-антиоксидантної системи за умови передопераційної корекції в пацієнтів із високим ризиком розвитку

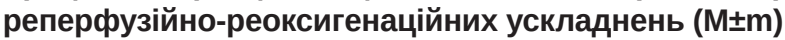

\begin{tabular}{|l|c|c|c|}
\hline \multicolumn{1}{|c|}{ Показник } & При госпіталізації & Після підготовки & Після операції \\
\hline ТБК-АП, нмоль/мг & $75,69 \pm 2,51$ & $60,19 \pm 3,62^{*}$ & $80,47 \pm 2,71^{\star *}$ \\
\hline Каталаза, нмоль/мг·с & $0,49 \pm 0,05$ & $0,54 \pm 0,08$ & $0,88 \pm 0,09$ ** \\
\hline СОД, од./мгНb & $0,96 \pm 0,18$ & $0,65 \pm 0,22^{\star}$ & $0,73 \pm 0,28$ \\
\hline ЦП, мг/мл & $251,16 \pm 6,41$ & $239,24 \pm 7,38$ & $255,35 \pm 7,12^{\star \star}$ \\
\hline
\end{tabular}

Примітка. * - достовірна різниця між показниками при госпіталізації та показниками після підготовки; *夫 - достовірна різниця між показниками після підготовки та показниками після операційного втручання. 
передопераційною підготовкою. Зокрема, активність вільнорадикального окиснення у хворих із цілеспрямованою передопераційною підготовкою після операційного втручання була нижчою на $11,94 \%(p<0,05)$ за активність вільнорадикального окислення в пацієнтів із стандартною передопераційною підготовкою.

Водночас у пацієнтів із спеціальною передопераційною підготовкою після реваскуляризації нижніх кінцівок уміст у сироватці крові каталази і ЦП був нижчим, відповідно, в 1,5 (p<0,05) та 1,3 $(p<0,05)$ раза за вміст у сироватці крові складових прооксидантно-антиоксидантної системи хворих із стандартною передопераційною підготовкою (табл. 2).

Наведені результати дослідження підтверджують ефективність застосування в передопераційний період комплексу препаратів із включенням альфа-токофреролу, корвітину і дають можливість проводити реваскуляризацію нижніх кінцівок за умови зниженої активності вільнорадикального окиснення.

Таблиця 2 - Ефективність корекції активності прооксидантно-антиоксидантної системи в пацієнтів

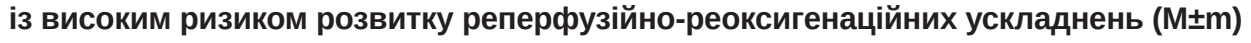

\begin{tabular}{|c|c|c|c|c|}
\hline \multirow[t]{2}{*}{ Показник } & \multicolumn{2}{|c|}{$\begin{array}{c}\text { Хворі з високим ризиком розвитку } \\
\text { реперсрузійних ускладнень }\end{array}$} & \multicolumn{2}{|c|}{$\begin{array}{c}\text { Хворі з високим ризиком розвитку } \\
\text { реперфрузійних ускладнень+корекція }\end{array}$} \\
\hline & до операції & після операції & до операції & після операції \\
\hline ТБК-АП, нмоль/МГ & $75,69 \pm 2,51$ & $98,11 \pm 3,22$ & $60,19 \pm 3,62^{*}$ & $80,47 \pm 2,71^{\star \star}$ \\
\hline Каталаза, нмоль/мг·с & $0,49 \pm 0,05$ & $1,35 \pm 0,17$ & $0,54 \pm 0,08$ & $0,88 \pm 0,09$ \\
\hline СОД, од./мгНb & $0,96 \pm 0,18$ & $0,54 \pm 0,14$ & $0,65 \pm 0,22^{*}$ & $0,73 \pm 0,28^{\star \star}$ \\
\hline ЦП, мг/мл & $251,16 \pm 6,41$ & $329,41 \pm 8,74$ & $239,24 \pm 7,38$ & $255,35 \pm 7,12^{\star \star}$ \\
\hline
\end{tabular}

Примітка. * - достовірна різниця між показниками хворих із стандартною підготовкою і пацієнтів із спеціальною передопераційною підготовкою до операційного втручання хворих; ** - достовірна різниця між показниками хворих із стандартною підготовкою і пацієнтів із спеціальною передопераційною підготовкою після операційного втручання хворих.

ВИСНОВОК. Застосування в передопераційний період у пацієнтів із високим ризиком виникнення реперфузійно-реоксигенаційних ускладнень альфа-токофреролу та кверцитину дає можливість запобігти значним порушенням розвитку ендотеліальної диссрункції та погіршенню фуункціонування мікроциркуляторного русла за рахунок підвищеної здатності прооксидантно-антиоксидантної рівноваги.

\section{СПИСОК ЛІТЕРАТУРИ}

1. Горобець Н. М. Нові стратегічні підходи до корекції ендотеліальної дисфункції / Н. М. Горобець // Ліки України. - 2015. - № 2 (188). - С. 20-24.

2. Геник С. М. Реперфузійний синдром після реваскуляризації ішемії нижніх кінцівок / С. М. Геник, А. В. Симчич // Серце і судини. - 2016. - № 3. C. 104-108.

3. Sabatine M. S. Evolocumab and clinical outcomes in patients with cardiovascular disease/ M. S. Sabatine, R. P. Giugliano, A. C. Keech // N. Engl. J. Med. - 2017. 376. - P. 1713-1722.

4. Strobl F. F. Twelve-month results of a randomized trial comparing mono with dual antiplatelet therapy in endovascularly treated patients with peripheral artery disease / K. Brechtel, J. Schmehl // J. Endovasc. Ther. 2013. - 20. - P. 699-706.

5. Critical limb ischemia: current trends and future directions / M. S. Conte, F. L. Moll, M. C. Verhaar, M. Teraa // J. Am. Heart Assoc. - 2016. - 5. e002938.

6. Гощинський В. Б. Місце терапевтичного неоангіогенезу в лікуванні критичної ішемії нижніх кінцівок /
В. Б. Гощинський, О. З. П'ятничка, Б. О. Мігенько //Art of medicine. - 2018. - № 4 (8). - C. 44-47.

7. Калинин Р. Е. Реперфузионное повреждение тканей в хирургии артерий нижних конечностей / Р. Е. Калинин, А. С. Пшенников, И. А. Сучков // Новости хирургии. - 2015. - № 3 (23). - С. 348-352.

8. Antoniou G. A. Statin therapy in lower limb peripheral arterial disease: systematic review and metaanalysis / R. K. Fisher, G. S. Georgiadis, S. A. Antoniou, F. Torella // Vascul. Pharmacol. - 2014. - 63. P. 79-87.

9. Дубинина Е. Е. Активность и кофрерментный спектр СОД эритроцитов / Е. Е. Дубинина, Л. Я. Сальникова, Л. Ф. Ефримова // Лаб. дело. - 1983. - № 10. C. $30-33$.

10. Fakhry F. Endovascular revascularization and supervised exercise for peripheral artery disease and intermittent claudication: a randomized clinical trial / F. Fakhry, S. Spronk, L. van der Laan // JAMA. - 2015. 314. - P. 1936-1944. 


\section{REFERENCES}

1. Horobets, N.M. (2015). Novi stratehichni pidkhody do korektsii endotelialnoi dysfunktsii [New strategic approaches to the correction of endothelial dysfunction]. Liky Ukrainy - Medicines of Ukraine, 2, 20-24 [in Ukrainian].

2. Henyk, S.M., \& Symchych, A.V. (2016). Reperfuziinyi syndrom pislia revaskuliaryzatsii ishemii nyzhnikh kintsivok [Reperfusion syndrome after lower limb ischemia revascularization]. Sertse $i$ sudyny - Heart and Blood Vessels, 3, 104-108 [in Ukrainian].

3. Sabatine, M.S., Giugliano, R.P., \& Keech, A.C. (2017). Evolocumab and clinical outcomes in patients with cardiovascular disease. N. Engl. J. Med. 376, 1713-1722

4. Strobl, F.F., Brechtel, K., \& Schmehl, J. (2013). Twelve-month results of a randomized trial comparing mono with dual antiplatelet therapy in endovascularly treated patients with peripheral artery disease. J. Endovasc. Ther., 20, 699-706.

5. Teraa, M., Conte, M.S., Moll, F.L., \& Verhaar, M.C. (2016). Critical limb ischemia: current trends and future directions. J. Am. Heart Assoc., 5, e002938.
6. Hoshchynskyi, V.B., Piatnychka, O.Z., Mihenko, B.O. (2018). Mistse terapevtychnoho neoanhiohenezu v likuvanni krytychnoi ishemii nyzhnikh kintsivok [The place of therapeutic neoangiogenesis in the treatment of critical ischemia of the lower extremities]. Art of Medicine, 4 (8), 44-47 [in Ukrainian].

7. Kalinin, R.E., Pshennikov, A.S., \& Suchkov, I.A. (2015). Reperfuzionnoe povrezhdenie tkaney v khirurgii arteriy nizhnikh konechnostey [Reperfusion tissue damage in surgery of lower limb arteries]. Novosti khirurgii Surgery News, 3 (23), 348-352.

8. Antoniou, G.A., Fisher, R.K., Georgiadis, G.S., Antoniou, S.A., \& Torella, F. (2014) Statin therapy in lower limb peripheral arterial disease: systematic review and meta-analysis. Vascul. Pharmacol., 63, 79-87.

9. Dubinina, E.E., Salnikova, L.Ya., \& Efimova, L.F. (1983). Aktivnost i kofermentnyy spektr SOD eritrotsitov [Activity and coenzyme spectrum of red blood cell SOD]. Lab. delo. - Laboratory Case, 10, 30-33 [in Russian].

10. Fakhry, F., Spronk, S., \& van der Laan L. (2015). Endovascular revascularization and supervised exercise for peripheral artery disease and intermittent claudication: a randomized clinical trial. JAMA, 314, 1936-1944.

\section{КОРРЕКЦИЯ ПРООКСИДАНТНО-АНТИОКСИДАНТНОГО РАВНОВЕСИЯ У ПАЦИЕНТОВ С КРИТИЧЕСКОЙ ИШЕМИЕЙ НИЖНИХ КОНЕЧНОСТЕЙ И ВЫСОКИМ РИСКОМ РАЗВИТИЯ РЕПЕРФУЗИОННО-РЕОКСИГЕНАЦИОННЫХ ОСЛОЖНЕНИЙ}

\section{Резюме}

Вступление. Облитерирующий атеросклероз магистральных перифрерических сосудов составляет более 20 \% случаев всей сердечно-сосудистой патологии, то есть более 3 \% общей численности населения. На современном этапе особую остроту приобретает проблема лечения больных с терминальными стадиями окклюзионных заболеваний артерий нижних конечностей - "критической ишемией", что соответствует 3-4 стадиям хронической ишемии по классифрикации Б. В. Покровского или III-IV - по Fontaine.

Цель исследования - изучить возможность коррекции прооксидантно-антиоксидантной системы у пациентов с хронической критической ишемией нижних конечностей и высоким риском развития реперфузионно-реоксигенационных осложнений после реконструктивных операций.

Методы исследования. В основу работы положен анализ комплексного обследования и хирургического лечения 220 больных облитерирующим атеросклерозом аорты и магистральных артерий нижних конечностей. Активность составляющих прооксидантно-антиоксидантной системы определяли с помощью спектрофотометрических методов, оптическую плотность измеряли на спектрофотометре "Biomat 5" (Великобритания).

Результаты и обсуждение. С целью коррекции прооксидантно-антиоксидантного равновесия в предоперационный период назначали альфра-токоферол и кверцитин. Применение препаратов позволило стабилизировать активность прооксидантно-антиоксидантной системы на момент проведения операционного вмешательства. В частности, в указанный период снизилась активность свободнорадикального окисления, о чем свидетельствовало уменьшение в 1,3 раза $(p<0,05)$ содержания активных продуктов тиобарбитуровой кислоты в сыворотке крови. В то же время снизилось в 1,5 раза $(p<0,05)$ содержание в сыворотке крови супероксиддисмутазы при незначительном возрастании содержания каталазы и постоянном содержании церулоплазмина. Результаты исследования подтверждают, что реваскуляризация нижних конечностей способствует активации прооксидантно-антиоксидантной системы и, прежде всего, повышению активности свободнорадикального окисления. 
Вывод. Применение в предоперационный период у пациентов с высоким риском возникновения реперфузионно-реоксигенационных осложнений альфа-токоферола и кверцитина позволяет предотвратить значительные нарушения развития эндотелиальной дисфункции и ухудшение фрункционирования микроциркуляторного русла за счет повышенной способности прооксидантно-антиоксидантного равновесия.

КЛЮЧЕВЫЕ СЛОВА: прооксидантно-антиоксидантная система; реперфузионно-реоксигенационные осложнения; альфа-токоферол; кверцитин; свободнорадикальное окисление.

\author{
O. B. Kolotylo
}

BUKOVINIAN STATE MEDICAL UNIVERSITY

\title{
CORRECTION OF PROOXIDANT-ANTIOXIDANT EQUILIBRIUM IN PATIENTS WITH CRITICAL ISCHEMIA OF THE LOWER EXTREMITIES AND A HIGH RISK OF DEVELOPMENT OF REPERFUSION-REOXIGENATION COMPLICATIONS
}

\section{Summary}

Introduction. Obliterating atherosclerosis of the main peripheral vessels accounts for more than $20 \%$ of all cardiovascular pathologies, that is, more than $3 \%$ of the total population. At the present stage, the problem of treating patients with terminal stages of occlusive diseases of the lower limb arteries - "critical ischemia", which corresponds to 3-4 stages of chronic ischemia according to B.V. Pokrovskyi or III-IV by Fontaine classification, is becoming especially acute.

The aim of the study - to learn the possibility of correcting the prooxidant-antioxidant systems in patients with chronic critical lower limb ischemia and a high risk of reperfusion - reoxygenation complications after reconstructive operations.

Research Methods. The analysis is based on a comprehensive examination and surgical treatment of 220 patients with obliterating atherosclerosis of the aorta and major arteries of the lower extremities. The activity of the constituents of the prooxidant-antioxidant system was determined using spectrophotometric methods, the optical density was measured on a Biomat 5 spectrophotometer (UK).

Results and Discussion. In order to adjust the prooxidant-antioxidant balance, alpha-tocopherol and quercetin were prescribed in the preoperative period. The use of drugs allowed to stabilize the activity of the prooxidantantioxidant system at the time of surgery. In particular, in the indicated period, the activity of free radical oxidation decreased, as evidenced by a decrease in $1.3(p<0.05)$ times the content of active thiobarbituric acid products in blood serum. At the same time, a decrease of $1.5(p<0.05)$ times in the blood serum superoxide dismutase was noted due to a slight increase in the catalase content and a constant content of ceruloplasmin. The results of the study confirm that revascularization of the lower extremities promotes the activation of the prooxidant-antioxidant system and, above all, an increase in the activity of free-radical oxidation.

Conclusion. The use of alpha-tocopherol and quercetin in patients with a high risk of reperfusion-reoxygenation complications in the preoperative period helps to prevent significant disturbances in the development of endothelial dysfunction and impaired functioning of the microvasculature due to the increased ability of prooxidant-antioxidant balance.

KEY WORDS: prooxidant-antioxidant system; reperfusion-reoxygenation complications; alphatocopherol; quercetin; free radical oxidation.

Адреса для листування: О. Б. Колотило, Буковинський державний медичний університет, пл. Театральна, 2, Чернівці, 58002, Україна, e-mail: kob79@i.ua. 